\title{
NOD2 receptors in adenopituitary folliculostellate cells: expression and function
}

\author{
Eliane Correa-de-Santana, Bianca Fröhlich, Marta Labeur, Marcelo Páez-Pereda ${ }^{\mathbf{1}}$, \\ Marily Theodoropoulou, Jose Luis Monteserin, Ulrich Renner and Günter K Stalla \\ Department of Endocrinology, Max Planck Institute of Psychiatry, Kraepelinstrasse 2-10, 80804 Munich, Germany \\ ${ }^{1}$ Affectis Pharmaceuticals, D-82152 Munich, Germany \\ (Correspondence should be addressed to E Correa-de-Santana; Email: santana@mpipsykl.mpg.de)
}

\begin{abstract}
Folliculostellate cells (FS cells) are non-endocrine cells from the pituitary gland that respond to bacterial endotoxins by producing cytokines. In immune cells, an important component of bacterial recognition are the toll-like receptors (TLRs). Previously, we showed that FS cells express TLR4. The TLR4 ligand lipopolysaccharide (LPS) stimulates interleukin-6 (IL6) production through nuclear factor $\mathrm{\kappa B}$ (NFKB) induction. Binding of IL6 to gp130 receptor activates signal transducer and activator of transcription 3 (STAT3), an important mediator of inflammatory response. Another family involved in innate immune response following bacterial infection is the nucleotide-binding oligomerisation domain (NOD) intracellular receptor family. Herein, we describe for the first time the expression and function of NOD receptors in human pituitary and FS TtT/GF cell line. The NOD2 agonist muramyl dipeptide (MDP) increased $N f \kappa b 1$-transcriptional activity, -protein expression and IL6 secretion in TtT/GF
\end{abstract}

cells. Furthermore, these effects were potentiated by the combination of MDP and LPS. Silencing NOD2 abolished the action of LPS on NFKB transcriptional activity and IL6 production, indicating that, in TtT/GF cells, TLR4 transduces its signal through NOD2 receptor. We show here that in TtT/GF cells, Nod 2 overexpression or stimulation by MDP increased STAT3 transcriptional activity. Furthermore, silencing STAT3 inhibited basal, LPS and MDP stimulated NFKB protein expression and overexpression of protein inhibitor of activated STAT3 (Pias3) markedly decreased basal NFKB activity. These data suggest that in TtT/GF cells, STAT3 acting upstream to NFKB mediates NOD2 receptor signalling pathway. In conclusion, the present study demonstrates that NOD molecules play a modulatory role in the pituitary by regulating the function and activation of FS cells in response to bacterial components.

Journal of Endocrinology (2009) 203, 111-122

\section{Introduction}

The neuroendocrine and the immune systems are interconnected anatomically and functionally. Both express and respond to common regulatory molecules such as cytokines, hormones, neuropeptides and neurotransmitters (Besedovsky \& Del 1992, 2002). Recent publications support the direct participation of folliculostellate (FS) cells in the immune-endocrine network. These cells are star-shaped and follicle-forming cells from the anterior pituitary gland (Renihart \& Farquhar 1953), which share properties with antigen presenting cells such as dendritic cells and macrophages by expressing S100 protein and major histocompatibility complex class II (Nakajima et al. 1980, Allaerts et al. 1996). Immune cells mediate the response to multiple bacterial cell wall components through a series of pattern recognition molecules expressed on the cell surface such as toll-like receptors (TLRs; Takeda et al. 2003). In response to cytokines released by activated immune cells,
FS cells produce several growth factors and cytokines, which modulate hormonal production by pituitary endocrine cells (Vankelecom et al. 1989, Koike et al. 1997, Bilezikjian et al. 2003, Herkenham 2005).

In addition, we have recently reported that the established FS cell line TtT/GF can be directly activated by bacterial components due to the expression of TLR 4 on the cell surface (Lohrer et al. 2000, Tichomirowa et al. 2005). In these cells, the TLR4 ligand lipopolysaccharide (LPS, Gramnegative bacteria-derived endotoxins) activates the nuclear factor $\kappa \mathrm{B}(\mathrm{N} f \kappa b)$, which induces the production of several cytokines such as interleukin-6 (IL6), a member of the gp130 family, which stimulates the production and secretion of ACTH, GH and prolactin (Arzt et al. 1993, 1999, Medzhitov \& Janeway 1997, Aderem \& Ulevitch 2000, Lohrer et al. 2000, Arzt 2001, Gloddek et al. 2001). The signal transducer and activator of transcription 3 (STAT3) was initially identified as an IL6 dependent transcription factor important for mediating the inflammatory response, tumorigenesis and 
anti-apoptotic effects on cells. In addition to its ability to form complexes to itself and other STATs there are several reports showing that STAT3 and NFKB interact with each other (Battle \& Frank 2002). NFKB p65 homodimers bind to phosphothyrosine STAT3 monomers. This interaction appears to increase transcriptional activity of genes driven by specific $\kappa \mathrm{B}$ elements (Yoshida et al. 2004). Moreover, inhibition of NFKB decreased IL6 production and STAT3 phosphorylation in squamous cell carcinoma (Squarize et al. 2006).

More recently, the nucleotide-binding oligomerisation domain (NOD)-like receptors family involved in the recognition of bacterial products within the cytosol have been detected in both immune and non-immune cell types (Girardin et al. 2003a, Ting \& Davis 2005). The protein NOD1 (also called CARD4) recognises the dipeptide $\gamma$-D-glutamyl-meso-diaminopimelic acid (iE-DAP; Chamaillard et al. 2003, Girardin et al. 2003b), which is produced by most Gram-negative and specific Gram-positive bacteria (Hasegawa et al. 2006). In contrast, NOD2 (also called CARD15) is activated by muramyl dipeptide (MDP), a component of all types of peptidoglycans (Girardin et al. 2003c, Inohara et al. 2003).

In the immune system, the interaction of NOD1 and NOD2 with its specific ligand initiates a cascade of signalling inducing NFKB activation and consequently cytokine production such as IL6, IL1 $\beta$ (IL1 $\beta$ ), IL8, and tumour necrosis factor- $\alpha$ (Ogura et al. 2001, Chin et al. 2002, Kobayashi et al. 2002, Fritz et al. 2005). In addition, NOD2and TLR4-agonists act in a synergic manner to induce cytokine secretion and dendritic cell maturation (Takada et al. 2002, Traub et al. 2004, Fritz et al. 2005).

In this study, we demonstrate for the first time the expression of NOD1 and NOD2 intracellular receptors in the pituitary gland and in $\mathrm{TtT} / \mathrm{GF}$ cells. The present work is focused on the function of NOD2.

Herein, we show a synergic action of NOD2 molecules with TLR 4 receptor on the induction of IL6 by NFKB in TtT/GF cells. Moreover, our data suggest that TLR4 might transduce its signals through NOD2 receptors. Notably, our results suggest that not only NFKB but also STAT3 participates in the NOD2 signalling pathway. These findings demonstrate that TLR and NOD receptors signalling pathways may significantly modulate the function of TtT/GF cells during bacterial infection and inflammation.

\section{Material and Methods}

\section{Reagents}

$\mathrm{N}$-acetylmuramyl-D-alanyl-D-isoglutamine (MDP-LD; L-isoform), $\quad N$-acetylmuramyl-L-alanyl-D-isoglutamine (MDP-DD; D-isoform, inactive) and iE-DAP were purchased from Invitrogen. LPS (Escherichia coli serotype 055:B5) was obtained from Sigma-Aldrich.

\section{Human pituitary}

Samples from five human pituitary glands were obtained from autopsy cases without any evidence of endocrinological disease, with postmortem delay between 8 and $12 \mathrm{~h}$. The tissues were snap-frozen and stored at $-80^{\circ} \mathrm{C}$. This study was performed after approval of the Ethics Committee of the Medical Faculty of the University of Munich (Ethic grant Nr. 141-07).

\section{Rat pituitary}

Female Sprague-Dawley rats (200-250 g) were obtained from the animal facilities of the Max Planck Institute of Psychiatry (Munich, Germany). The animals were kept in an environment of constant temperature, humidity and day-night cycle; food and water were made available ad libitum. Glands were obtained within minutes of the animals' death by decapitation and were treated as indicated below. All experimental procedures were approved by the Ethics Committee of the Max Planck Institute.

\section{Cell culture}

The pituitary mouse FS cell line TtT/GF and human embryonic kidney cells (HEK-293) were cultured in DMEM supplemented with $10 \%$ heat-inactivated fetal bovine serum (FBS), 2.2 g/l $\mathrm{NaHCO}_{3}, 10 \mathrm{mM}$ Hepes, $2 \mathrm{mM}$ glutamine, $10^{5} \mathrm{U} / 1$ penicillin-streptomycin. The cells were maintained at $37^{\circ} \mathrm{C}$ in humidified $\mathrm{CO}_{2}$ atmosphere.

\section{Immunohistochemistry}

For immunohistochemistry, $8-\mu \mathrm{m}$ sections of rat pituitary tissue were thaw-mounted onto Super Frost Plus slides (Menzel-Glaser, Hamburg, Germany). TtT/GF cell line was grown for $48 \mathrm{~h}$ in multiwell plates at $37^{\circ} \mathrm{C}$ and $5 \% \mathrm{CO}_{2}$. Afterwards, pituitary sections and $\mathrm{TtT} / \mathrm{GF}$ cultures were fixed in $4 \%$ paraformaldehyde in TBS, and stored in $96 \%$ ethanol, at $4{ }^{\circ} \mathrm{C}$ until use. Slides were first washed thrice for $5 \mathrm{~min}$ in PBS and then incubated for $30 \mathrm{~min}$ in serum (1:10) of the same animal in which specific biotinylated secondary antibody was raised. Subsequently, the corresponding slides were incubated overnight at $4{ }^{\circ} \mathrm{C}$ with goat polyclonal NOD2 antibody (1:200) or with rabbit polyclonal NFKB (p65)/Rel A (1:300) (Santa Cruz Biotechnology, Inc., Santa Cruz, CA, USA) as indicated in the figure legends. After washing thrice in TBS, the corresponding biotinylated secondary antibody (1:300) was added at room temperature for $30 \mathrm{~min}$. The slides were again rinsed thrice in TBS and incubated for $30 \mathrm{~min}$ with avidin-biotin-peroxidase complex (Vector Laboratories Inc., Burlingame, CA, USA) at room temperature. Colour development was performed using

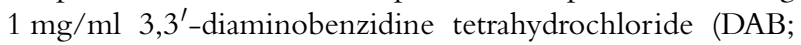
Sigma) with $0 \cdot 01 \%$ hydrogen peroxidase applied for $2 \mathrm{~min}$. Finally, after washing in deionised water, the sections were 
counterstained in toluidine blue, fixed in Roti-Histol (Roth, Karlsruhe, Germany) and coverslipped using Roti-Histokit (Roth). Negative controls were performed by omitting the primary antibody where no staining was detected.

\section{Double immunofluorescence}

For the detection of NOD2, we used a goat polyclonal NOD2 antibody (Santa Cruz Biotechnology) (1:200). For S100, a marker of FS cells, we used a rabbit anti-S100 serum (1:3000) (Swant, Bellinzona, Switzerland). The slides were incubated with $1 \%$ Tris-base saline buffer, $\mathrm{pH} 7 \cdot 6 / \mathrm{BSA}$ for $30 \mathrm{~min}$ at room temperature followed by incubation in a cocktail containing goat anti-NOD2 and rabbit anti-S100 in TBS, $\mathrm{pH} 7.64{ }^{\circ} \mathrm{C}$ overnight. After incubation, overnight sections were washed and incubated with Alexa 488-conjugated donkey anti-goat $\operatorname{IgG}(1: 1000)$ and Alexa 594-conjugated goat anti-rabbit IgG (1:1000) (Molecular probes, Eugene, OR, USA) for $45 \mathrm{~min}$ at room temperature. Sections were counterstained with $1 \mathrm{~g} / \mathrm{ml} \mathrm{4,6-diaminidino-}$ 2-phenylidole (Vector Laboratories). Finally, sections were mounted with Vectashield (Vector Laboratories) and investigated using a confocal laser scanning microscope (LSM 510, Carl Zeiss, Jena, Germany). To ensure the specificity of the double-immunostaining procedure, control experiments were performed in which the primary antibodies were omitted. No staining was observed under these conditions.

\section{RT-PCR}

Total cellular RNA was prepared from normal pituitaries and $\mathrm{Tt} \mathrm{T} / \mathrm{GF}$ cells using TRIzol reagent (Life Technologies Inc.) following the manufacturer's protocol. RNA extraction was followed by a DNase digestion step to remove any contaminating genomic DNA. One microgram RNA from normal pituitaries and cell cultures was reverse transcribed to cDNA using Superscript II reverse transcriptase (Life Technologies, Inc). With the cDNA template obtained, a PCR was performed with the following specific primers: mouse Nod1 upper primer: 5' CTCTCACTGTACAGGTCTGTTTCTTC 3'; mouse Nod1 lower primer: $5^{\prime}$ CAACTTCTGAgGACATGAagATACTTT $3^{\prime}$; PCR product length of $350 \mathrm{bp}$; mouse Nod2 upper primer: 5' GAAAGACAGCTCCATTTTATTTATGAC 3'; mouse Nod2 lower primer: $5^{\prime}$ GCTTTCACCTCTGTGATTATTTATAGC $3^{\prime}$; PCR product length of $300 \mathrm{bp}$; mouse Tlr 4 upper primer: $5^{\prime}$ GGG TCAAGGAACAGAAGCAG 3'; mouse Tlr4 lower primer: GCTCATTTC TCACCCAGTCC; PCR product length of $264 \mathrm{bp}$; human Nod1 upper primer: 5' GTAAAGGTGCTAAGCGAAGA $3^{\prime}$; human NOD1 lower primer: $5^{\prime}$ TCTGATTCTGGATAAGCCAT $3^{\prime}$; PCR product length of $470 \mathrm{bp}$; human NOD2 upper primer: $5^{\prime}$ AACCACTCTCTGTGCGGACT 3'; human NOD2 lower primer: $5^{\prime}$ CCTGTTCAGAGAAGCCCTTG $3^{\prime}$; PCR product length of $310 \mathrm{bp}$. Rat Nod2 upper primer: $5^{\prime}$ AGTGAAGGCAAATGGACTGG; rat Nod2 lower primer: TCTGTCCGCAGCTCTAAGGT; PCR product length of $219 \mathrm{bp}$. D-glyceraldehyde-3-phosphate dehydrogenase (Gapdh) upper primer: $5^{\prime}$ ATGGTGAAGGTCGGTGTGAACG 3'; Gapdh lower primer: 5' GTTGT CATGGATGACCTTGGC $3^{\prime}$; PCR product length of $495 \mathrm{bp}$.

RT reactions were carried out in a $20 \mu \mathrm{l}$ final volume by adding $1 \mu \mathrm{g}$ total RNA, $1 \mu \mathrm{l}$ Superscript II, $10 \mu \mathrm{M}$ dNTP mixture, and $250 \mathrm{ng}$ random hexamer primers. The reaction mixtures were incubated at $45^{\circ} \mathrm{C}$ for $1 \mathrm{~h}$. Finally, reactions were terminated by heating at $94^{\circ} \mathrm{C}$ for $5 \mathrm{~min}$ and cooling on ice. PCR analysis was applied to assess the expression of NOD1 and NOD2 in mouse and human pituitary glands, and $\mathrm{TtT} / \mathrm{GF}$ cell cultures with specific primers under 38 amplification cycle non-saturating conditions using a Thermocycler-Techgene (Labtech International, Ringmer, East Sussex, UK). Amplified samples were visualised on 1.5\% agarose gels stained with ethidium bromide and photographed under u.v. light.

\section{Transfections assays}

Briefly, TtT/GF cells were seeded on six-well plates and were transfected at $80 \%$ density using Lipofectamine 2000 reagent (Invitrogen Corp.) according to the manufacturer's instructions. Following $24 \mathrm{~h}$ transfection, the cells were stimulated with MDP or LPS as indicated in the legends to the figures. After stimulation, cells were lysed in cell lysis buffer (Promega Corp.) and luciferase activity was measured with the addition of luciferin detection reagent (Promega Corp). Transfection efficiency was determined using the RSV- $\beta$-gal construct as previously described (Páez-Pereda et al. 2001). The results are ratios of luciferase to $\beta$-gal activity. Results are expressed as percentage respect to control plasmids or basals. Since NOD expression is restricted to the cytoplasm, we delivered MDP and iE-DAP directly into the cytoplasm using Lipofectamine 2000 reagent (Invitrogen Corp). Transient transfections were performed using the following reporter plasmids: NF- $\kappa B$ luciferase ( $\kappa \mathrm{B}-\mathrm{LUC}$ ) plasmid provided by Dr Bell (Mayo Clinic, Rochester, MN, USA); pIL6 luciferase (651) containing nucleotides -651 to +1 of the human IL6 promoter upstream of the luciferase gene (Eickelberg et al. 1999); and pSTAT3 luciferase obtained from Addgene, Cambridge, MA, USA. Nod2 expression plasmid (pcDNA3 HA-Nod2) and control plasmid (pcDNA3 HA) were from Dr Gabriel Nunez (University of Michigan Medical School, Ann Arbor, MI, USA). I $\mathrm{B}$ super-repressor construct containing the mutated site at Ser 32 and 36 was kindly provided by Dr Altschmidt, Institut für Neurobiochemie, University of Witten/Herdecke, Witten, Germany. Pias3 expression plasmid clone into PCMVJFLAG vector was provided from Dr Sohn, University of California, LA, USA. 


\section{RNA interference}

SiRNA for targeting endogenous NOD2 and STAT3 were from Santa Cruz Biotechnology, Inc. A non-targeting siRNA sequence (Santa Cruz Biotechnology, Inc.) was used as a control (siRNA control) for all transfection experiments. $\mathrm{TtT} / \mathrm{GF}$ cells were cultured in six-well plates as described in the section 'Transfection assays', and transfected using $13 \mathrm{nM}$ siRNA. After $18 \mathrm{~h}$ transfection, the medium was removed and the cells were cultured in DMEM supplemented with 2\% FCS for a further $24 \mathrm{~h}$. Then the cells were stimulated as indicated in the legends to the figures. At the end of the treatment, the lysates were collected and luciferase activity was measured. Culture supernatants were collected and assayed for cytokine production as indicated in the legends to the figures.

\section{Western blot analysis}

Proteins were extracted from TtT/GF cells after stimulation with MDP, LPS each, alone or in combination. The total protein content was determined with Bradford method for

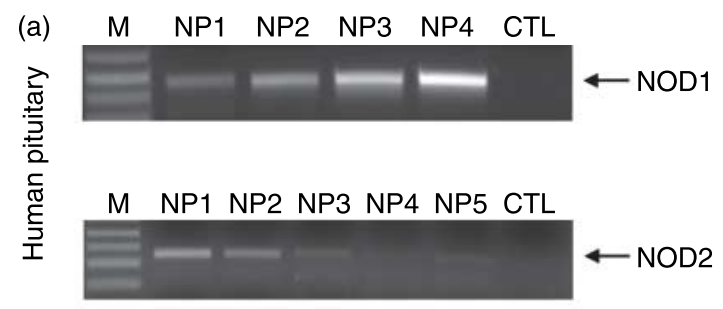

(b) $\quad \mathrm{M}$
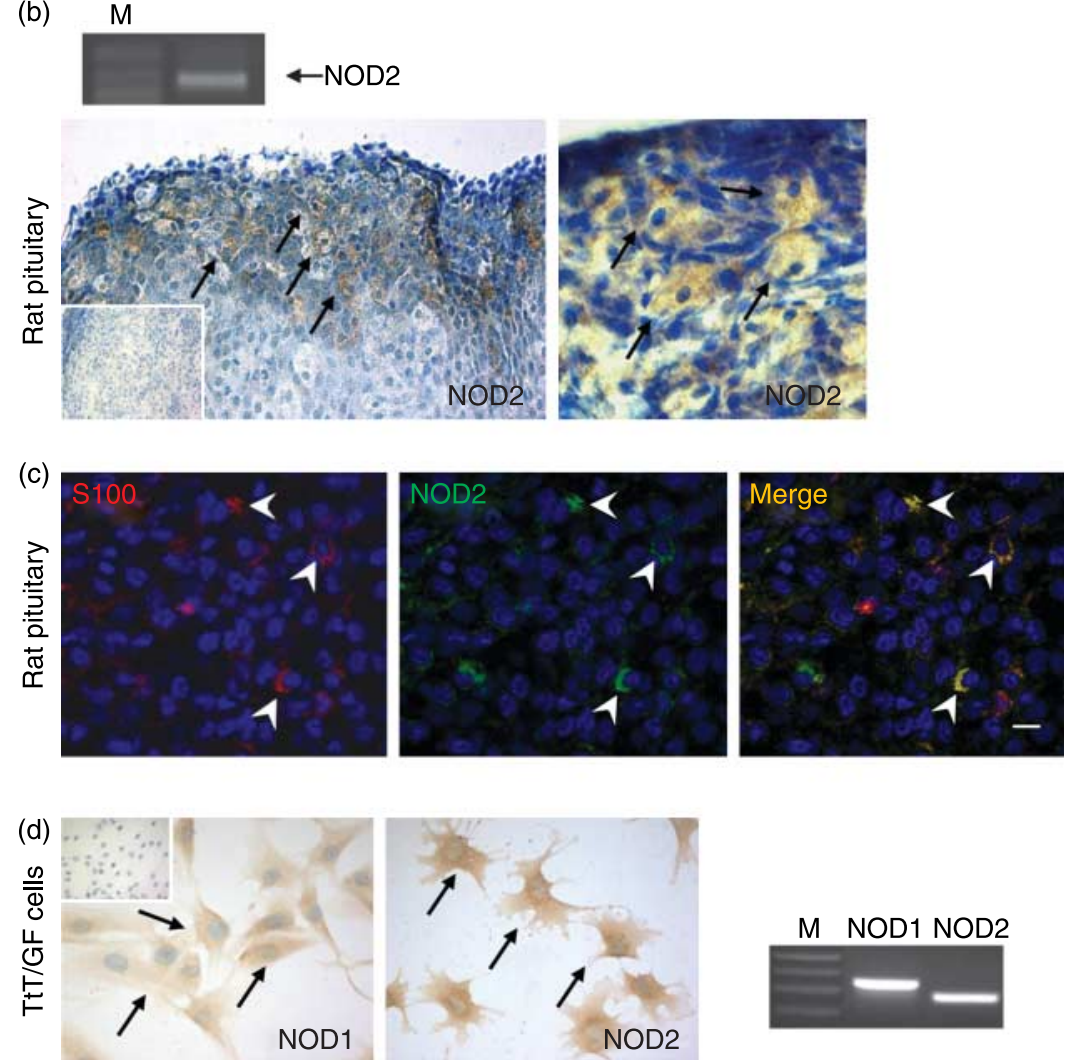

Figure 1 NOD1 and NOD2 expression in the pituitary gland and TtT/GF cells. (a) Detection of NOD1 and NOD2 in the human normal pituitary gland (NP) by transcriptase chain reaction (RT-PCR). (b) Detection of NOD2 in rat pituitary by RT-PCR and immunohistochemistry. The images are depicted at the magnification of $\times 40$ and $\times 100$. (c) Dual immunofluorescence by co-localisation of S100 protein and NOD2 in rat pituitary gland. Scale bar represents $10 \mu \mathrm{m}$. (d) Detection of NOD1 and NOD2 by immunohistochemistry and RT-PCR analysis in mouse TtT/GF cell lines. The images are depicted at the magnification of $\times 40$. Inserts represent a background labelling when the primary antibody was omitted. 


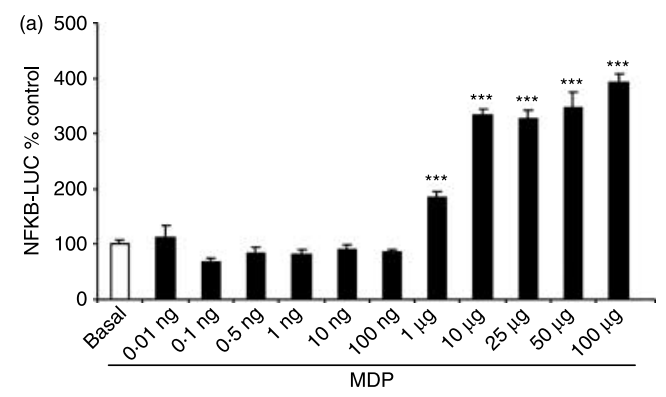

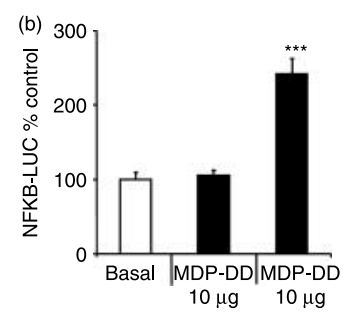

(d)

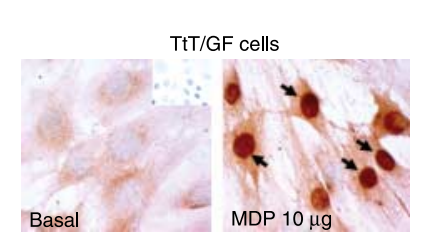

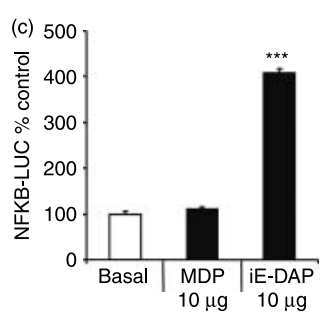

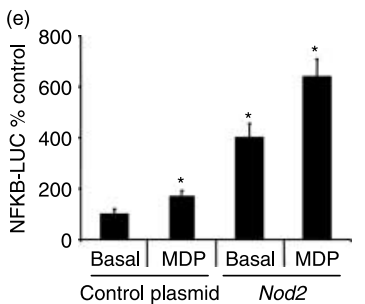

Figure 2 NFKB activation and nuclear localisation in TtT/GF cells. (a) $2.5 \times 10^{5} \mathrm{TtT} / \mathrm{GF}$ cells were transfected with $\kappa B$-LUC plasmid in the presence of MDP $(0 \cdot 01 \mathrm{ng} / \mathrm{ml}$ to $100 \mu \mathrm{g} / \mathrm{ml})$. Six hours posttransfection, NFKB luciferase activity was measured. (b) $2.5 \times 10^{5}$ $\mathrm{TtT} / \mathrm{GF}$ cells were transfected with $\kappa \mathrm{B}-\mathrm{LUC}$ plasmid in the presence of active MDP, MDP-LD $(10 \mu \mathrm{g} / \mathrm{ml})$ or inactive MDP, MDP-DD $(10 \mu \mathrm{g} / \mathrm{ml})$. Six hours post-transfection, NFKB luciferase activity was measured. (c) HEK-293 cells $\left(2 \cdot 5 \times 10^{5}\right)$ were co-transfected with $\kappa B-L U C$ plasmid in the presence of iE-DAP or MDP at the concentration of $10 \mu \mathrm{g} / \mathrm{ml}$. After $24 \mathrm{~h}$, the cells were lysed and NFKB activity was analysed. (d) TtT/GF cells were transfected with MDP $(10 \mu \mathrm{g} / \mathrm{ml})$ for $6 \mathrm{~h}$. After, cell cultures were fixed and stained with NFKB (p65/Rel A) antibody. Immunohistochemical analyses indicate the translocation of NFKB (black arrows) to the nucleus of cells after stimulation. Inserts represent a background labelling when the primary antibody was omitted. (e) TtT/GF cells were transiently transfected with control plasmids or Nod2 expression vector along with $\kappa \mathrm{B}$-LUC plasmid with or without MDP at the concentration of $5 \mu \mathrm{g} / \mathrm{ml}$. Twenty-four hours posttransfection, luciferase activity was measured. Values indicate the mean + S.E.M. of triplicates from one representative experiment $(n=3) .{ }^{*} P<0.05$ and ${ }^{* * *} P<0.001$ versus control plasmids or basal.

further normalisation. Samples containing equal amounts of protein $(10 \mu \mathrm{g})$ were separated by SDS-PAGE (10\% gels), followed by electrotransfer to nitrocellulose membrane. Membranes were blocked with non-fat milk in TBST (50 mM Tris, pH 7·5, $150 \mathrm{mM} \mathrm{NaCl}, 0 \cdot 1 \%$ Tween 20) for $2 \mathrm{~h}$ at room temperature, and probed with anti-NFKB p65/Rel A or anti-STAT3 (Santa Cruz Biotechnology, Inc.) antibodies diluted in a ratio of $1: 500$ in $2.5 \%$ non-fat milk in
TBST for $2 \mathrm{~h}$ at room temperature or overnight at $4{ }^{\circ} \mathrm{C}$. After washing, the membranes were further incubated with peroxidase-conjugated anti-rabbit $\operatorname{IgG}(1: 1000)$ used as secondary antibody for $1 \mathrm{~h} 30 \mathrm{~min}$. After washing, the bands were revealed by enhanced chemiluminescence (Amersham Biosciences).

\section{Determination of cytokine production in culture supernatants}

Following 6 h stimulation with LPS alone or in combination with MDP, cell culture supernatants were removed and stored at $-20{ }^{\circ} \mathrm{C}$. Mouse IL6 was measured using specific ELISA kits (R\&D Systems, Minneapolis, MN, USA) according to the manufacturer's instructions.

\section{Statistical analysis}

All experiments were performed at least three times to confirm the reproducibility of the results. All results show a representative of three experiments. Differences were assessed by Student's $t$-test or by one-way ANOVA in combination with the Bonferonni's test (Figs 3a, $4 \mathrm{~b}$ and 5d). Differences were considered statistically significant when $P$ values were $<0 \cdot 05$. Statistical results are express as mean \pm s.E.M.

\section{Results}

NOD2 expression in the pituitary gland and TtT/GF cells

NOD1 and NOD2 are expressed in different organs (Rodríguez-Martínez et al. 2005, Davey et al. 2006, Sterka \& Marriott 2006, Uehara \& Takada 2007, Uehara et al. 2007, Stroh et al. 2008), but there is no previous evidence of NOD expression in the pituitary gland. We detected for the first time NOD1 and NOD2 transcripts in human pituitary gland (Fig. 1a). NOD2 transcripts were also detected in rat pituitary (Fig. 1b). Moreover, NOD2 immunoreactivity was detected in cells localised in clusters, exhibiting irregular shape and extruded long cytoplasmic processes typical of FS cells (Fig. 1b). Dual colour immunofluorescence in rat pituitaries using antibodies against NOD2 and the FS cell marker S100 protein confirmed NOD2 expression in FS cells (Fig. 1c). Interestingly, NOD2 was not only expressed in FS cells but also in some S100-negative cells (Fig. 1c). Consistent with these findings, we detected in mouse TtT/GF cell lines the expression of NOD1 and NOD2 receptors (Fig. 1d). These results demonstrate that NOD molecules are expressed in FS cells.

\section{NOD2 induced NFKB activation in TtT/GF cells}

To determine the functional significance of NOD2 receptors in the FS cells, we first analysed the effects of NOD2 receptor ligand, MDP, on the activation of NFKB. Different MDP 

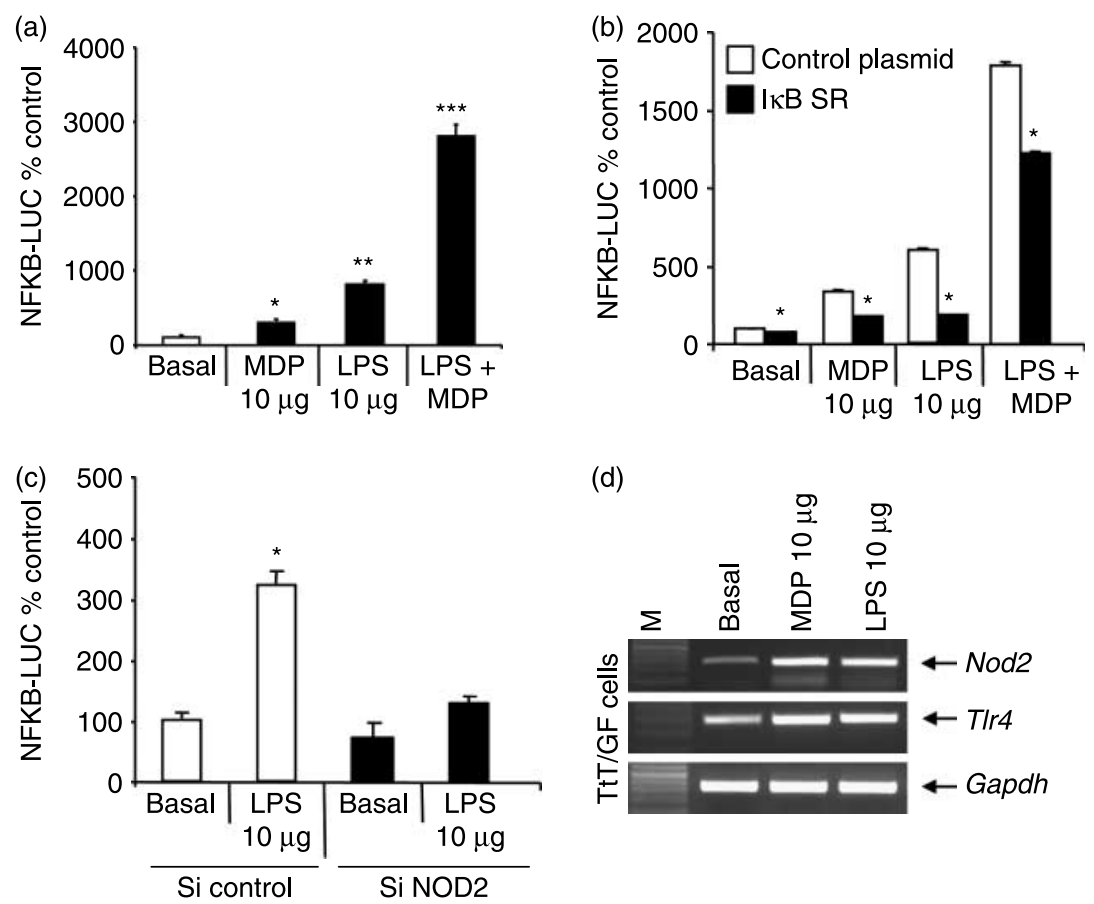

Figure 3 Synergism between MDP and LPS on NFKB activation in TtT/GF. $2 \cdot 5 \times 10^{5} \mathrm{TtT} / \mathrm{GF}$ cells were co-transfected with $\kappa B$-LUC plasmid in the presence of: (a) MDP $(10 \mu \mathrm{g} / \mathrm{ml})$ and/or LPS $(10 \mu \mathrm{g} / \mathrm{ml})$. Twenty-four hours post-transfection cells were collected and $N f_{\kappa} b$ transcriptional activity was determined by luciferase activity. (b) I $\kappa$ B super-repressor (I $\mathrm{k} B \mathrm{sr}$ ) plasmid, MDP and/or LPS for $6 \mathrm{~h}$. (c) TtT/GF cells were co-transfected with $\kappa B$-LUC plasmid with NOD2 siRNA (black bars) or with control siRNA (white bars). Forty-eight hours posttransfection, cells cultures were treated with LPS $(10 \mu \mathrm{g})$ for $6 \mathrm{~h}$. (d) MDP and LPS upregulate NOD2 and T/r4 mRNA levels. TtT/GF cells were stimulated with MDP $(10 \mu \mathrm{g} / \mathrm{ml})$ and LPS $(10 \mu \mathrm{g} / \mathrm{ml})$ for $24 \mathrm{~h}$. RNAs extracted from these cells were subjected to RT-PCR analysis. Values indicate the mean \pm S.E.M. of triplicates from one representative experiment $(n=3)$. ${ }^{*} P<0 \cdot 05,{ }^{* *} P<0 \cdot 01$ and ${ }^{* * *} P<0 \cdot 001$ versus basal.

concentrations were tested in TtT/GF cells. We found that from $10 \mu \mathrm{g} / \mathrm{ml}$ on, MDP-induced NFKB transcriptional activity by around $2 \cdot 5$-fold (Fig. 2a). The inactive MDP isomer, MDP-DD, which is not recognised by NOD2 was used as a negative control (Girardin et al. 2003c, Inohara et al. 2003). Using MDP-DD did not enhance NFKB transcriptional activity (Fig. 2b). HEK-293 cells that express NOD1, but do not express detectable levels of NOD2 are accepted as a model to evaluate the specificity of NOD2 ligand (Ogura et al. 2001). We observed that NFKB in HEK-293 cells did not respond to MDP treatment but was activated by the NOD1 ligand iE-DAP (Fig. 2c) demonstrating that the MDP treatment is selective for NOD2 in our experiments. Furthermore, we observed by immunohistochemistry that MDP induced NF- $\kappa B$ nuclear translocation indicating that NFKB may modulate gene transcription in the nucleus (Fig. 2d). In addition, NOD2 overexpression in $\mathrm{TtT} / \mathrm{GF}$ cells increased basal and MDP induced NFKB transcriptional activity (Fig. 2e).

These results demonstrate that $\mathrm{TtT} / \mathrm{GF}$ cells express functional NOD2 receptors.
MDP potentiated the effects of LPS on NFKB transcriptional activity through NOD2

Several studies show that TLR4 induces NFKB transcriptional activity after binding to LPS and that NOD and TLR 4 can synergistically activate NFKB in a variety of cells (Fritz et al. 2005, Uehara \& Takada 2007, Zhao et al. 2007). In addition, silencing TLR 4 significantly abolished the LPS-induced NFKB activity as expected (data not shown). To elucidate whether MDP also potentiates the LPS-induced NFKB activation in FS cells, TtT/GF cells were stimulated with MDP in combination with LPS for 6 and $24 \mathrm{~h}$. LPS increased NFKB transcriptional activity, and its action was potentiated by co-treatment with MDP (Fig. 3a). These results demonstrate a synergistic action between NOD2 agonist, MDP and TLR4 agonist, LPS on the activation of NFKB in TtT/GF cell cultures.

We evaluated the transcriptional activation of $N f \kappa b$ by MDP or/and LPS in the presence of a super-repressor form of $\mathrm{I} \kappa \mathrm{B}$, resistant to phosphorylation and proteolic degradation. Consistent with the results showed in Fig. 3a, 

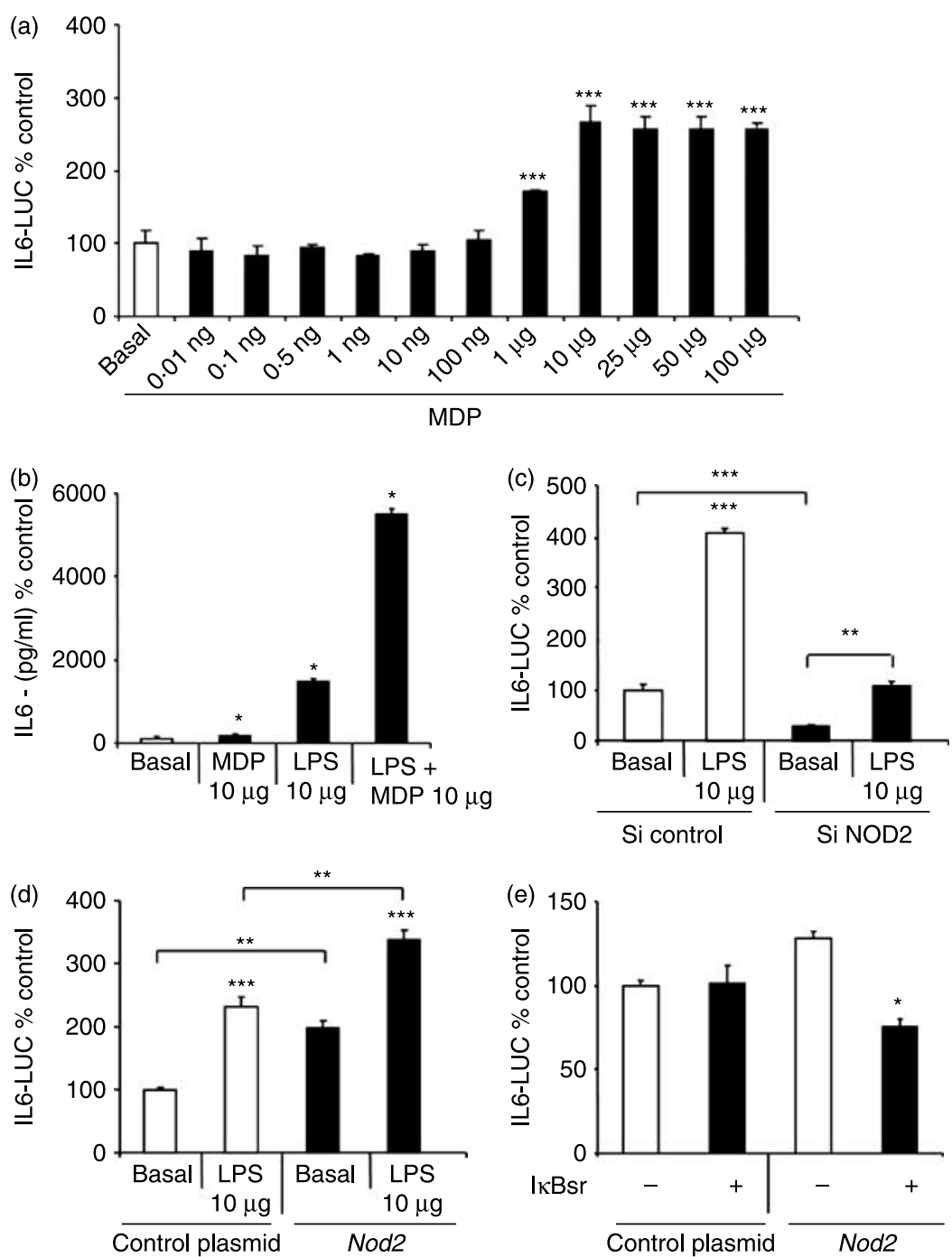

Figure 4 Induction of IL6 secretion by MDP and/or LPS. (a) Cell cultures were exposed to MDP at different concentrations $(0 \cdot 01 \mathrm{ng} / \mathrm{ml}$ to $100 \mu \mathrm{g} / \mathrm{ml})$ for $6 \mathrm{~h}$. Six hours posttransfection, IL6 luciferase activity was measured. (b) Cell cultures were exposed to MDP and/or LPS for $6 \mathrm{~h}$. IL6 levels in culture supernatants were measured by ELISA. (c) Cell cultures were co-transfected with IL6-LUC plasmid and siRNA NOD2 (black bars) or with control siRNA (white bars). Forty-eight hours post-transfection, cells were treated with LPS $(10 \mu \mathrm{g})$ for $6 \mathrm{~h}$. IL6 activity was measured. ${ }^{* *} P<0 \cdot 001$; Si control plus LPS versus basal, Si NOD2 versus Si control, Si NOD2 plus LPS versus Si control plus LPS, ${ }^{* *} P<0 \cdot 01$; Si NOD2 plus LPS versus NOD2. (d) TtT/GF cells cultures were co-transfected with IL6 reporter plasmid along with control plasmid or Nod2 expression plasmid with and without LPS $(10 \mu \mathrm{g} / \mathrm{ml})$. Twenty-four hours after transfection, IL6 activity was measured.

${ }^{* * *} P<0 \cdot 001$; LPS versus basal, $* * P<0 \cdot 01 ;$ Nod 2 versus control plasmid, Nod 2 plus LPS versus control plasmid plus LPS. (e) Cells were transfected with IL6 reporter and I $\kappa$ B superrepressor in the presence of control plasmid or NOD2 expression plasmid as indicated in the figure. Twenty-four hours after transfection, IL6 was assessed. ${ }^{*} P<0 \cdot 05, * * P<0 \cdot 01$ and ${ }^{* * *} P<0 \cdot 001$ versus basal. Values indicate the mean \pm s.E.M. of triplicates from one representative experiment $(n=3)$.

the overexpression of $I \kappa \mathrm{B}$ super-repressor totally abolished the MDP and LPS-induced NFKB transcriptional activity (Fig. 3b), showing a specific induction of NFKB. Furthermore, the synergistic effect of MDP plus LPS was significantly inhibited by the $\kappa \mathrm{B}$ repressor (Fig. 3b). However, the effect of $\mathrm{I} \kappa \mathrm{B}$ super-repressor at this particular concentration was not strong enough to block the synergism. 
(a)

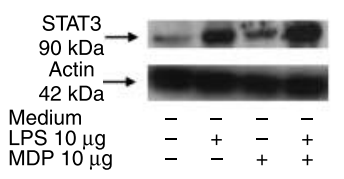

(b)

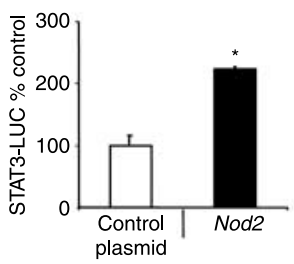

(c)

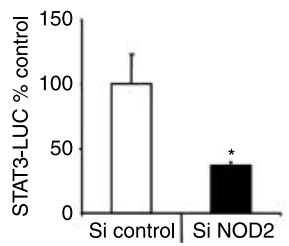

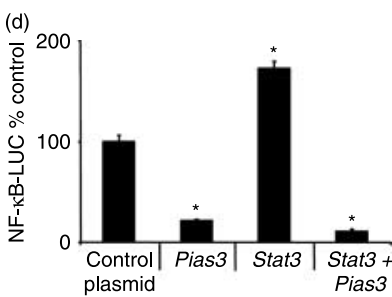

(e)

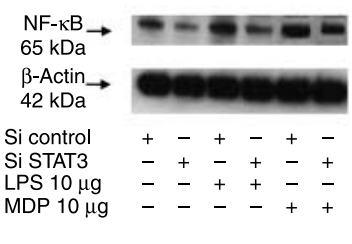

Figure 5 Involvement of NFKB and STAT3 on NOD2 signalling pathway. (a) TtT/GF cells were stimulated with LPS $(10 \mu \mathrm{g} / \mathrm{ml})$ and/or MDP $(10 \mu \mathrm{g} / \mathrm{ml})$ for $24 \mathrm{~h}$. Cell lysates were resolved in $10 \%$ SDS gel and subjected to western blotting analyses. Nitrocellulose membranes were immunoblotted with STAT3 antibody. (b) TtT/GF cells cultures were co-transfected with STAT3 along reporter plasmid along with control plasmid or Nod2 expression plasmid. Twenty-four hours after transfection, luciferase activity was measured. (c) TtT/GF cells cultures were co-transfected with STAT3 reporter plasmid along with control siRNA or siRNA NOD2. Twenty-four hours after transfection, luciferase activity was measured. (d) TtT/GF cells were transfected with Stat3 and/or Pias3 expression plasmids. pcDNA3 was used as control plasmid. Twenty-four hours post-transfection, NF- $\kappa B$ activity was measured. (e) Cells were transfected with STAT3 siRNA or control siRNA as indicated. Forty-eight hours post-transfection, the cells were stimulated with LPS $(10 \mu \mathrm{g} / \mathrm{ml})$ and MDP $(10 \mu \mathrm{g} / \mathrm{ml})$ each alone or in combination for $6 \mathrm{~h}$. Total cell lysates were immunoblotted with NFKB (p65Rel A) and $\beta$-actin specific antibodies. Values indicate the mean \pm s.E.M. of triplicates from one representative experiment $(n=3) . P<0 \cdot 05$, versus control plasmids or basal.

To further clarify the synergistic role of NOD2 and TLR4 on the NFKB transcriptional activity, TtT/GF cells were transfected with NOD2 siRNA. Interestingly, silencing NOD2 receptor impaired LPS-induced NFKB activation (Fig. 3c), suggesting that NOD2 receptors might be necessary for LPS/TLR4-induced activation of FS cells.

In addition, we estimated the effect of LPS and MDP on the expression of TLR4 and NOD2 receptors in TtT/GF cells. Cell cultures were stimulated with LPS $(10 \mu \mathrm{g} / \mathrm{ml})$ or MDP $(10 \mu \mathrm{g} / \mathrm{ml})$ for $24 \mathrm{~h}$. Both ligands seem to upregulate mRNA levels of NOD2 and TLR4 (Fig. 3d), as detected by RT-PCR, a process that could enhance the response of these cells to microbial products.

MDP and LPS synergistically induced IL6 production through NOD2

LPS-induced NFKB activation plays an important role in the regulation of IL6 synthesis in TtT/GF cells (Lohrer et al. 2000). Since MDP induces NFKB activation, we examined whether this induction could also enhance IL6 transcriptional activity in TtT/GF cells. Indeed, $10 \mu \mathrm{g} / \mathrm{ml}$ MDP stimulated IL6 activation (Fig. 4a), in accordance with previous studies in immune cells (Tada et al. 2005, Uehara et al. 2005, Yang \& Stark 2008). To determine whether there was a cooperative effect between MDP and LPS on the IL6 synthesis, TtT/GF cells were treated with LPS alone or in combination with MDP. LPS significantly induced IL6 production and MDP potentiated this effect (Fig. 4b). Next, we analysed the role of NOD2 receptor in LPS-induced IL6 transcriptional activity. For this purpose, TtT/GF cells were transfected with NOD2 siRNA and IL6 activity was determined in the presence or absence of LPS. NOD2 silencing impaired the LPS-induced IL6 production in TtT/GF cells (Fig. 4c). This data expanded our previous results on the LPS-induced NFKB activation in the presence of NOD2 siRNA, where the NOD2 receptors appeared to be critical for the TLR4-induced activation of FS cells.

In addition, we found that Nod 2 overexpression induced IL6 promoter activity and potentiates the effect of LPS (Fig. 4d), further indicating the importance of NOD2 on the modulation of IL6 synthesis in TtT/GF cells. To analyse whether NFKB mediates the IL6 production in these cells, $\mathrm{I} \kappa \mathrm{B}$ super-repressor was co-transfected together with the Nod2 expression plasmid. I $\mathrm{B}$ super-repressor inhibited the Nod2-stimulated IL6 promoter activity (Fig. 4e), demonstrating that Nod 2 induces the production of IL 6 in TtT/GF cells via NFKB.

Altogether, these findings indicate that NOD2 modulates basal and LPS-induced IL6 production through the activation of NFKB in TtT/GF cells.

\section{NFKB activation by NOD2 requires STAT3}

IL6-activated STAT3 and IL-1-induced NFKB were shown to physically interact and increase the transcriptional activity of $\kappa \mathrm{B}$ sites (Zhang \& Fuller 1997, Yoshida et al. 2004). Therefore, the role of STAT3 in MDP and MDP/LPS-induced NFKB activation in TtT/GF cell lines was investigated. First, we observed that MDP and LPS increased STAT3 protein expression, and that MDP potentiated LPS-induced STAT3 protein expression (Fig. 5a). Next, we observed that the overexpression of Nod2 in TtT/GF cells induced STAT3 activity (Fig. 5b). In contrast, silencing of NOD2 using siRNA interference resulted in the decrease of STAT3 transcriptional activity (Fig. 5c). Interestingly, Stat3 overexpression induced NFKB activation in TtT/GF cells cultures, whereas the inhibitor of activated STAT3 (Pias3) inhibited basal NFKB and 


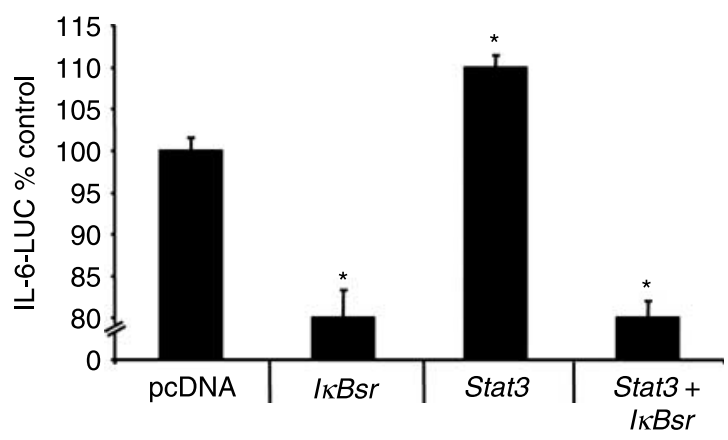

Figure 6 Involvement of NFKB on STAT3-induced IL6 promoter. Cell cultures were co-transfected with IL6-LUC in the presence of Stat 3 alone or in combination of IKBsr. IL6 promoter activity was measured after $24 \mathrm{~h}$.

abolished the effect of Stat3 overexpression on NFKB transcriptional activity (Fig. 5d). These data indicate that STAT3 modulates the activation of NFKB in TtT/GF cells. Consistently, silencing STAT3 decreased the protein level of the NFKB subunit p65/RelA (Fig. 5e). Moreover, STAT3 downregulation abolished the effect of LPS and MDP on NFKB protein expression (Fig. 5e). Thus, STAT3 is necessary for the NFKB induction in TtT/GF cells and STAT3/NFKB participates in the NOD2 signalling pathway.

These results show that Nod2 induces STAT3 transcriptional activity in TtT/GF cells. Moreover, the findings indicate that STAT3 is important for the stimulatory action of LPS and MDP on NFKB, suggesting that STAT3 acts downstream to TLR4 and NOD2 signalling pathways.

\section{STAT3-induced IL6 promoter activity is mediated by NFKB in TtT/GF cells}

The role of STAT3 and NFKB on the IL6 production in $\mathrm{TtT} / \mathrm{GF}$ cells was further examined. Stat3 overexpression slightly increased IL6 under basal conditions, and this enhancement is abolished when NFKB activation is blocked by I $\mathrm{B}$ super-repressor (Fig. 6).

\section{Discussion}

The aim of this work was to study the expression and function of NOD2 receptors in the FS cell line TtT/GF. We report for the first time that NOD2 receptors significantly modulate the function of $\mathrm{TtT} / \mathrm{GF}$ cells during stimulation with microbial cell wall components. Moreover, our data demonstrate a synergic action of NOD2 with TLR4 on the induction of IL- 6 by NFKB, and that STAT3 acting downstream to the NOD2 receptor participates in this induction.

In the present work, we provide evidence for the constitutive expression of NOD2 in the human and rat pituitary and in TtT/GF cells. Double immunofluorescence of rat normal pituitary gland revealed that FS cells and some S100-negative cells of the adenohypophysis display a high level of NOD2. Furthermore, we observed that in TtT/GF cells, MDP and LPS seem to increase Nod 2 and Tlr 4 mRNA, consistently with the finding of Takahashi et al. (2006). They demonstrated that Nod2 expression was up-regulated in immune cells stimulated with LPS and NOD agonists. In addition, we found that unliganded Nod2 has a basal level of activity in TtT/GF cells since the overexpression studies show changes in $I l 6$ transcriptional activity and STAT3 signalling even in the absence of LPS and MDP agonist. Therefore, it is tempting to speculate that changes in the levels of Nod2 expression might be enough to induce pathophysiological alterations in the pituitary gland. The NOD2 receptor expression indicates a possible direct MDP action on FS cells in the pituitary gland. Binding of MDP to its receptor dose-dependently induces $N f k b$ transcriptional activity, in agreement with previous report in immune cells (Ogura et al. 2001, Chin et al. 2002, Inohara et al. 2002, Kobayashi et al. 2002). This data indicates that the NOD2-signalling pathway is functional in TtT/GF cells. The specificity of the MDP/ NOD2 receptor binding was confirmed using NOD2 receptor lacking cells, HEK-293 (Ogura et al. 2001). As we expected in these cells, MDP did not induce NFKB activity, whereas the iE-DAP NOD1 receptor ligand did. Moreover, we observed that the overexpression of NOD2 activates basal and MDP-induced $N f \kappa b$ transcriptional activity further confirming the functionality of this receptor in $\mathrm{TtT} / \mathrm{GF}$ cells. TLR and NOD receptors have been reported to trigger the activation of macrophages and dendritic cells by inducing $N f k b$ transcriptional activity, MAP kinases activation and cytokine production in cells from the immune system (Dumitru et al. 2000, McDonald et al. 2005, Kim et al. 2008). Moreover, NOD and TLR receptors can act in a cooperative manner inducing activation of immune cells (Fritz et al. 2005, Uehara et al. 2005). Several studies conducted with immune cell lines or using peripheral blood mononuclear cells have reported that MDP together with LPS highly increases NFKB activation and cytokine production (Bertin et al. 1999, Inohara et al. 1999). Since previous studies showed that TLR4 is expressed on the membrane of $\mathrm{TtT} / \mathrm{GF}$ cells (Lohrer et al. 2000), we investigated whether LPS and MDP act in a synergic manner on these cells. In agreement with the literature on the immune system, our experiment demonstrated that MDP in combination with LPS synergistically induced NFKB activation on $\mathrm{TtT} / \mathrm{GF}$ cells. In addition, we showed that siRNA targeting NOD2 significantly blocked the NFKB activation induced by LPS as revealed by NFKB reporter gene activation (Fig. 3c). These demonstrate a role of NOD2 receptors in mediating the LPS-induced NFKB activation in $\mathrm{TtT} / \mathrm{GF}$ cells, suggesting that TLR 4 may transduce its signals through NOD2. Thus, in TtT/GF cells a functional NOD2 receptor might be critical not only for the transductions of signals of MDP but also for the response to LPS. Nevertheless, Kobayashi et al. (2005) showed in a study of macrophages from 
NOD-deficient mouse that responses to LPS were generally equivalent in wild-type and NOD2 knockout mice. Therefore, the involvement of NOD2 in the TLR4 signal transduction might be specific for FS cells, although further studies are needed to test this hypothesis.

Considering that NFKB has been described to induce the production of IL6, we assessed IL6 protein expression and transcriptional activity in $\mathrm{TtT} / \mathrm{GF}$ cells treated with MDP. We found that MDP not only affected NFKB activity but also increased IL6 production in TtT/GF cells in a dose-dependent manner. Additionally, we clearly demonstrated that MDP potentiated the effect of LPS on the induction of IL6 in FS cells. These results are in accordance with the literature that showed that MDP stimulates pro-inflammatory cytokine production in immune cells and that MDP and LPS cooperatively amplified this production (Ogura et al. 2001, Chin et al. 2002, Kobayashi et al. 2002, Fritz et al. 2005). Therefore, our results confirm that FS cells are involved in the intrapituitary response to infection.

Interestingly, we found that NOD2 siRNA abolished LPSinduced IL6 production in TtT/GF cells and overexpression of NOD2 induced additional stimulation of cells by LPS, further confirming our data on NFKB and reflecting once more the importance of NOD2 on the TLR 4 pathway. The activity of IL6 promoter was found to be significantly enhanced in $\mathrm{TtT} / \mathrm{GF}$ cells overexpressing Nod2, while NOD2 siRNA inhibited this activation. As in the immune system (Medzhitov \& Janeway 1997, Aderem \& Ulevitch 2000, Lohrer et al. 2000, Gloddek et al. 2001) in TtT/GF cells, IL6 synthesis is mediated by the activation of the $\mathrm{NF}-\kappa \mathrm{B}$, since the presence of $\mathrm{I} \kappa \mathrm{B}$ repressor inhibited the cytokine production.

We also demonstrate evidence for a novel mechanism that involve the synthesis of STAT3 protein and transcriptional activity after activation of the NOD2 receptor. Thus, MDP stimulation and NOD2 overexpression result in the synthesis and activation of STAT3 in TtT/GF cells. Whether IL6 mediates the stimulation of STAT3 is currently under investigation.

Cross-talk between transcription factors has become a commonly recognised mode of gene regulation (Yoshida et al. 2004). In vivo, STAT3 can physically interact with NFKB p65 and p65 homodimers cooperate with STAT3 when bound to specific types of $\kappa \mathrm{B}$ motifs (Yoshida et al. 2004). In this report, we demonstrate an interaction between STAT3 and NFKB, which may contribute to the activation of IL6. Silencing STAT3 either by using siRNA or by overexpressing Pias3 abolished NFKB transcriptional activity, indicating the participation of STAT3 in the activation of NFKB. Whether STAT3 and NFKB bind each other at the level of IL6 promoter remains to be elucidated.

These findings demonstrate that NOD2 receptor activation significantly modulates the function of TtT/GF cells during bacterial infection and inflammation.
A major concern using siRNAs is the non-specific activation of the immune-signalling pathways (Marques \& Williams 2005). In this direction, it was described that siRNAs delivered to the cytoplasm of mammalian cells can be recognised by TLRs such as TLR3, TLR7 and TLR8. Once recognised, these siRNAs may produce off-targets effects inducing the activation of immune signalling. In contrast, in our experiments, the NOD2 and STAT3 siRNAs had no stimulatory effects under basal conditions and did not potentiate the stimulatory effect of LPS. Moreover, basal and LPS effects were blocked in the presence of NOD2 and STAT3 siRNAs. These data demonstrate that we have no off-target stimulatory effects produced by siRNAs. Moreover, we noticed that the luciferase activity levels measured after transfection with control plasmids were comparable with the levels that were obtained after the treatment with silencing control RNA.

The importance of understanding the regulatory events within the pituitary gland during infection or inflammation is exemplified by the role that hormones play in adapting the endocrine system to the activated immune system. Thus, intrapituitary IL6 produced by FS cells may act in a paracrine manner to module endocrine cell function by inducing hormone production (Renner et al. 1996, Ray \& Melmed 1997), and by affecting pituitary cell growth in response to external stimuli (Renner et al. 1998). In turn, the activated HPA axis will prevent an over-reaction of the stimulated immune system (Elenkov et al. 1999, Chrousos 2000).

\section{Declaration of interest}

The authors declare that there is no conflict of interest that would prejudice the impartiality of the research reported.

\section{Funding}

This work was supported by a grant from German Research Foundation (Deutsche Forschungsgemeinschaft - DFG: ON 79/1-1).

\section{Acknowledgements}

We are grateful to Dr Gabriel Nunez (University of Michigan Medical School, Ann Arbor, MI, USA) for providing the Nod2 expression plasmid. We thank Dr Marcus Panhuysen for technical advice (Affectis Biotechnology, GmBH).

\section{References}

Aderem A \& Ulevitch RJ 2000 Toll-like receptors in the induction of the innate immune response. Nature 406 782-787.

Allaerts W, Fluitsma DM, Hoefsmit EC, Jeucken PH, Morreau H, Bosman FT \& Drexhage HA 1996 Immunohistochemical, morphological and ultrastructural resemblance between dendritic cells and folliculostellate cells in normal human and rat anterior pituitaries. Journal of Neuroendocrinology 8 17-29.

Arzt E 2001 gp130 Cytokine signaling in the pituitary gland: a paradigm for cytokine-neuro-endocrine pathways. Journal of Clinical Investigation 108 1729-1733.

Arzt E, Buric R, Stelzer G, Stalla J, Sauer J, Renner U \& Stalla GK 1993 Interleukin involvement in anterior pituitary cell growth regulation: effects of IL-2 and IL6. Endocrinology 132 459-467. 
Arzt E, Pereda MP, Castro CP, Pagotto U, Renner U \& Stalla GK 1999 Pathophysiological role of the cytokine network in the anterior pituitary gland. Frontiers in Neuroendocrinology 20 71-95.

Battle TE \& Frank DA 2002 The role of STATs in apoptosis. Current Molecular Medicine 2 381-392.

Bertin J, Nir WJ, Fischer CM, Tayber OV, Errada PR, Grant JR, Keilty JJ, Gosselin ML, Robison KE, Wong GH et al. 1999 Human CARD4 protein is a novel CED-4/Apaf-1 cell death family member that activates NFKB. Journal of Biological Chemistry 274 12955-12958.

Besedovsky HO \& Del RA 1992 Immune-neuroendocrine circuits: integrative role of cytokines. Frontiers in Neuroendocrinology 13 61-94.

Besedovsky HO \& Del RA 2002 Introduction: immune-neuroendocrine network. Frontiers of Hormone Research 29 1-14.

Bilezikjian LM, Leal AM, Blount AL, Corrigan AZ, Turnbull AV \& Vale WW 2003 Rat anterior pituitary folliculostellate cells are targets of interleukin1 beta and a major source of intrapituitary follistatin. Endocrinology 144 $732-740$.

Chamaillard M, Hashimoto M, Horie Y, Masumoto J, Qiu S, Saab L, Ogura Y, Kawasaki A, Fukase K, Kusumoto S et al. 2003 An essential role for NOD1 in host recognition of bacterial peptidoglycan containing diaminopimelic acid. Nature Immunology 4 702-707.

Chin AI, Dempsey PW, Bruhn K, Miller JF, Xu Y \& Cheng G 2002 Involvement of receptor-interacting protein 2 in innate and adaptive immune responses. Nature 416 190-194.

Chrousos GP 2000 The stress response and immune function: clinical implications. The 1999 Novera H. Spector Lecture. Annals of the New York Academy of Sciences 917 38-67.

Davey MP, Martin TM, Planck SR, Lee J, Zamora D \& Rosenbaum JT 2006 Human endothelial cells express NOD2/CARD15 and increase IL6 secretion in response to muramyl dipeptide. Microvascular Research $\mathbf{7 1}$ 103-107.

Dumitru CD, Ceci JD, Tsatsanis C, Kontoyiannis D, Stamatakis K, Lin JH, Patriotis C, Jenkins NA, Copeland NG, Kollias G et al. 2000 TNF- $\alpha$ induction by LPS is regulated posttranscriptionally via a Tpl2/ERKdependent pathway. Cell 103 1071-1083.

Eickelberg O, Pansky A, Mussmann R, Bihl K, Tamm M, Hildebrand P, Perruchoud AP \& Roth M 1999 Transforming growth factor-beta1 induces interleukin-6 expression via activating protein-1 consisting of JunD homodimers in primary human lung fibroblasts. Journal of Biological Chemistry 274 12933-12938.

Elenkov IJ, Webster EL, Torpy DJ \& Chrousos GP 1999 Stress, corticotropinreleasing hormone, glucocorticoids, and the immune/inflammatory response: acute and chronic effects. Annals of the New York Academy of Sciences 876 1-11.

Fritz JH, Girardin SE, Fitting C, Werts C, Mengin-Lecreulx D, Caroff M, Cavaillon JM, Philpott DJ \& Adib-Conquy M 2005 Synergistic stimulation of human monocytes and dendritic cells by Toll-like receptor 4 and NOD1- and NOD2-activating agonists. European Journal of Immunology 35 2459-2470.

Girardin SE, Travassos LH, Herve M, Banot D, Boneca IG, Philpott DJ, Sansonetti PJ \& Mengin-Lecreulx D 2003a Peptidoglycan molecular requirements allowing detection by Nod1 and Nod2. Journal of Biological Chemistry 278 41702-41708.

Girardin SE, Boneca IG, Carneiro LA, Antignac A, Jéhanno M, Viala J, Tedin K, Taha MK, Labigne A, Zähringer U et al. $2003 b$ Nod1 detects a unique muropeptide from gram-negative bacterial peptidoglycan. Science 300 1584-1587.

Girardin SE, Boneca IG, Viala J, Chamaillard M, Labigne A, Thomas G, Philpott DJ \& Sansonetti PJ 2003c Nod2 is a general sensor of peptidoglycan through muramyl dipeptide (MDP) detection. Journal of Biological Chemistry 278 8869-8872.

Gloddek J, Lohrer P, Stalla J, Arzt E, Stalla GK \& Renner U 2001 The intrapituitary stimulatory effect of lipopolysaccharide on ACTH secretion is mediated by paracrine-acting IL6. Experimental and Clinical Endocrinology \& Diabetes 109 410-415.

Hasegawa M, Yang K, Hashimoto M, Park JH, Kim YG, Fujimoto Y, Nuñez G, Fukase K \& Inohara N 2006 Differential release and distribution of Nod1 and Nod2 immunostimulatory molecules among bacterial species and environments. Journal of Biological Chemistry 39 29054-29063.

Herkenham M 2005 Folliculo-stellate (FS) cells of the anterior pituitary mediate interactions between the endocrine and immune systems. Endocrinology 146 33-34.

Inohara N, Koseki T, del Peso L, Hu Y, Yee C, Chen S, Carrio R, Merino J, Liu D, Ni J et al. 1999 Nod1, an Apaf-1-like activator of caspase- 9 and nuclear factor-kB. Journal of Biological Chemistry 274 14560-14567.

Inohara N, Ogura Y \& Nuñez G 2002 Nods: a family of cytosolic proteins that regulate the host response to pathogens. Current Opinion in Microbiology $\mathbf{5}$ 76-80.

Inohara N, Ogura Y, Fontalba A, Gutierrez O, Pons F, Crespo J, Fokase K, Inamura $\mathrm{S}$, Kusumoto $\mathrm{S}$, Hashimoto $\mathrm{M}$ et al. 2003 Host recognition of bacterial muramyl dipeptide mediated through NOD2. Implications for Crohn's disease. Journal of Biological Chemistry 278 5509-5512.

Kim YG, Park JH, Shaw MH, Franchi L, Inohara N \& Núñez G 2008 The cytosolic sensors Nod1 and Nod2 are critical for bacterial recognition and host defense after exposure to Toll-like receptor ligands. Immunity 28 246-257.

Kobayashi K, Inohara N, Hernandez LD, Galan JE, Nunez G, Janeway CA, Medzhitov R \& Flavell RA 2002 RICK/Rip2/CARDIAK mediates signalling for receptors of the innate and adaptive immune systems. Nature 416 194-199.

Kobayashi KS, Chamaillard M, Ogura Y, Henegariu O, Inohara N, Nuñez G \& Flavell RA 2005 Nod2-dependent regulation of innate and adaptive immunity in the intestinal tract. Science 307 731-734.

Koike K, Zhang ZX, Sakamoto Y, Kanda Y, Murakami K, Miyake A \& Inoue M 1997 The pituitary folliculo-stellate cell line TtT/GF augments basal and TRH-induced prolactin secretion by GH3 cell. Life Sciences 61 2491-2497.

Lohrer P, Gloddek J, Nagashima AC, Korali Z, Hopfner U, Pereda MP, Arzt E, Stalla GK \& Renner U 2000 Lipopolysaccharide directly stimulates the intrapituitary interleukin-6 production by folliculostellate cells via specific receptors and the p38alpha mitogen-activated protein kinase/nuclear factor-kappaB pathway. Endocrinology 141 4457-4465.

Marques JT \& Williams BR 2005 Activation of the mammalian immune system by siRNAs. Nature Biotechnology 23 1399-1405.

McDonald C, Inohara N \& Nuñez N 2005 Peptidoglycan signaling in innate immunity and inflammatory disease. Journal of Biological Chemistry $\mathbf{2 8 0}$ 20177-20180.

Medzhitov R \& Janeway CA Jr 1997 Innate immunity: the virtues of a nonclonal system of recognition. Cell 91 295-298.

Nakajima T, Yamaguchi H \& Takahashi K 1980 S100 protein in folliculostellate cells of the rat pituitary anterior lobe. Brain Research $191523-531$.

Ogura Y, Inohara N, Benito A, Chen FF, Yamaoka S \& Nunez G 2001 Nod2, a Nod1/Apaf-1 family member that is restricted to monocytes and activates NF-kappaB. Journal of Biological Chemistry 276 4812-4818.

Páez-Pereda M, Kovalovsky D, Hopfner U, Theodoropoulou M, Pagotto U, Uhl E, Losa M, Stalla J, Grübler Y, Missale C et al. 2001 Retinoic acid prevents experimental Cushing syndrome. Journal of Clinical Investigation 108 1123-1131.

Ray D \& Melmed S 1997 Pituitary cytokine and growth factor expression and action. Endocrine Reviews 18 206-228.

Renihart JF \& Farquhar MG 1953 Electron microscopic studies of the anterior pituitary gland. Journal of Histochemistry and Cytochemistry 1 93-113.

Renner U, Pagotto U, Arzt E \& Stalla GK 1996 Autocrine and paracrine roles of polypeptide growth factors, cytokines and vasogenic substances in normal and tumorous pituitary function and growth: a review. European Journal of Endocrinology 135 515-532. Review.

Renner U, Gloddek J, Pereda MP, Arzt E \& Stalla GK 1998 Regulation and role of intrapituitary IL6 production by folliculostellate cells. Domestic Animal Endocrinology 15 353-362. Review.

Rodríguez-Martínez S, Cancino-Díaz ME, Jiménez-Zamudio L, GarcíaLatorre E \& Cancino-Díaz JC 2005 TLRs and NODs mRNA expression pattern in healthy mouse eye. British Journal of Ophthalmology 89 904-910. 
Squarize CH, Castilho RM, Sriuranpong V, Pinto DS Jr \& Gutkind JS 2006 Molecular cross-talk between the NFKB and STAT3 signaling pathways in head and neck squamous cell carcinoma. Neoplasia 8 733-746.

Sterka D Jr \& Marriott I 2006 Characterization of nucleotide-binding oligomerization domain (NOD) protein expression in primary murine microglia. Journal of Neuroimmunology 179 65-75.

Stroh T, Batra A, Glauben R, Fedke I, Erben U, Kroesen A, Heimesaat MM, Bereswill S, Girardin S, Zeitz M et al. 2008 Nucleotide oligomerization domains 1 and 2: regulation of expression and function in preadipocytes. Journal of Immunology 181 3620-3627.

Tada H, Aiba S, Shibata K, Ohteki T \& Takada H 2005 Synergistic effect of Nod1 and Nod2 agonists with Toll-like receptor agonists on human dendritic cells to generate interleukin-12 and Thelper type 1 cells. Infection and Immunity 73 7967-7976.

Takada H, Yokoyama S \& Yang S 2002 Enhancement of endotoxin activity by muramyldipeptide. Journal of Endotoxin Research 8 337-342.

Takahashi Y, Izugawa K, Murase Y, Imai M, Yamamoto S, Iizuka M, Akira S, Bahr GM, Momotani E, Hori M et al. 2006 Up-regulation of NOD1 and NOD2 through TLR4 and TNF- $\alpha$ in LPS-treated murine macrophages. Journal of Veterinary Medical Science 68 471-478.

Takeda K, Kaisho T \& Akira S 2003 Toll-like receptors. Annual Review of Immunology 21 335-376.

Tichomirowa M, Theodoropoulou M, Lohrer P, Schaaf L, Losa M, Uhl E, Lange M, Arzt E, Stalla GK \& Renner U 2005 Bacterial endotoxin (lipopolysaccharide) stimulates interleukin-6 production and inhibits growth of pituitary tumour cells expressing the Toll-like receptor 4 . Journal of Neuroendocrinology 17 152-160.

Ting JP \& Davis BK 2005 CATERPILLER: a novel gene family important in immunity, cell death, and diseases. Annual Review of Immunology 23 387-414.

Traub S, Kubasch N, Morath S, Kresse M, Hartung T, Schmidt RR \& Hermann C 2004 Structural requirements of synthetic muropeptides to synergize with lipopolysaccharide in cytokine induction. Journal of Biological Chemistry 279 8694-8700.

Uehara A \& Takada H 2007 Functional TLRs and NODs in human gingival fibroblasts. Journal of Dental Research 86 249-254.
Uehara A, Yang S, Fujimoto Y, Fukase K, Kusumoto S, Shibata S, Sugawara S \& Takada H 2005 Muramyldipeptide and diaminopimelic acidcontaining desmuramylpeptides in combination with chemically synthesized Toll-like receptor agonists synergistically induced production of interleukin-8 in a NOD2- and NOD1-dependent manner, respectively, in human monocytic cells in culture. Cellular Microbiology 7 53-61.

Uehara A, Fujimoto Y, Fukase K \& Takada H 2007 Various human epithelial cells express functional Toll-like receptors, NOD1 and NOD2 to produce anti-microbial peptides, but not proinflammatory cytokines. Molecular Immunology 44 3100-3111.

Vankelecom H, Carmeliet P, Van DJ, Billiau C \& Denef C 1989 Production of interleukin- 6 by folliculo-stellate cells of the anterior pituitary gland in a histiotypic cell aggregate culture system. Neuroendocrinology 49 102-106.

Yang J \& Stark GR 2008 Roles of unphosphorylated STATs in signaling. Cell Research 18 443-451.

Yoshida Y, Kumar A, Koyama Y, Peng H, Arman A, Boch JA \& Auron PE 2004 Interleukin 1 activates STAT3/nuclear factor-kappa B cross-talk via a unique TRAF6-and p65-dependent mechanism. Journal of Biological Chemistry 279 1768-1776.

Zhang Z \& Fuller GM 1997 The competitive binding of STAT3 and NFKB on an overlapping DNA binding site. Biochemical and Biophysical Research Communications 237 90-94.

Zhao L, Kwon MJ, Huang S, Lee JY, Fukase K, Idnohara N \& Hwang DH 2007 Differential modulation of nods signaling pathways by fatty acids in human colonic epithelial HCT116 cells. Journal of Biological Chemistry 282 11618-11628.

Received in final form 14 July 2009

Accepted 15 July 2009

Made available online as an Accepted Preprint 16 July 2009 